\title{
Nota
}

\section{NPK FERTILIZATION ON INITIAL GROWTH OF PHYSIC NUT SEEDLINGS IN QUARTZARENIC NEOSSOL ${ }^{(1)}$}

\author{
Patrícia Teixeira de Souza ${ }^{(2)}$, Enilson de Barros Silva ${ }^{(3)}$, Paulo \\ Henrique Grazziotti ${ }^{(4)} \&$ Luiz Arnaldo Fernandes ${ }^{(5)}$
}

\begin{abstract}
SUMMARY
Balanced fertilization is important for plant growth. There is little information on physic nut (Jatropha curcas $L$.) and tests with the fertilization of the species are very recent. This study evaluated the initial growth of physic nut seedlings in response to NPK rates to Quartzarenic Neossol in a greenhouse and estimated $P$ and $K$ critical soil levels and $N, P$ and $K$ in shoot dry matter after 120 days of evaluation. The treatments were arranged in a randomized, fractional factorial design $(4 \times 4 \times 4)^{1 / 2}$, totalizing 32 treatments with three replicates, 96 experimental plots and $N$ rates $\left(0,75,150\right.$ and $\left.300 \mathrm{mg} \mathrm{dm}^{-3}\right)$ as urea; $P$ rates $(0,45,90$ and $\left.180 \mathrm{mg} \mathrm{dm}^{-3}\right)$ as triple superphosphate and $\mathrm{K}$ rates $\left(0,50,100\right.$ and $\left.200 \mathrm{mg} \mathrm{dm}^{-3}\right)$ as potassium chloride. After 120 days, the plants were harvested and some variables evaluated: plant height, stem diameter, shoot and root dry weight, macro and micronutrient levels in plant shoots, and soil chemical properties. The physic nut seedlings responded to NPK fertilizer in the initial growth phase; the response to $N$ was negative. The recommended $P$ and $K$ rates were 25 and $67 \mathrm{mg} \mathrm{dm}^{-3}$, respectively. The critical levels, corresponding to the recommended $P$ rate were 13 and $74 \mathrm{mg} \mathrm{dm}^{-3}$ for $\mathrm{K}$ in soil (Mehlich-1). The $\mathrm{N}, \mathrm{P}$ and $\mathrm{K}$ levels in the shoot dry matter of physic nut were $37.4,2.1$ and $35.7 \mathrm{~g} \mathrm{~kg}^{-1}$, respectively.
\end{abstract}

Index terms: Mineral fertilization, Jatropha curcas, oleaginous species.

\footnotetext{
(1) Part of the Master of Science Dissertation in Vegetable Production presented by the first author at the Universidade Federal dos Vales do Jequitinhonha e Mucuri, UFVJM, Diamantina (MG), Brazil. Paper presented at the XXXII CBCS, Fortaleza, CE, of 02 to 07 August 2009. Work funded by CNPq and FAPEMIG. Received for publication in august 2010 and approved in january 2011.

(2) Master in Vegetable Production, UFVJM. Rua da Gloria 187, CEP 39100-000 Diamantina (MG), Brazil. CAPES Scholarship holder. E-mail: patricia_tsouza@hotmail.com

(3) Department of Agronomy, UFVJM. CNPq Scholarship E-mail: ebsilva@ufvjm.edu.br

(4) Department of Forestry, UFVJM. E-mail: grazziotti@yahoo.com.br

(5) Institute of Agricultural Sciences, UFMG. E-mail: larnaldo@ufmg.br
} 


\title{
RESUMO: ADUBAÇÃO NPK NO CRESCIMENTO INICIAL DE MUDAS DE PINHÃO-MANSO EM NEOSSOLOQUARTZARÊNICO
}

\begin{abstract}
A adubação balanceada é importante para o crescimento das plantas. O pinhão-manso (Jatropha curcas L.) é uma espécie sobre a qual as informações são escassas, sendo muito recentes ensaios com adubação. Este trabalho teve o objetivo de avaliar o crescimento inicial de mudas de pinhão-manso em resposta às doses de NPK em casa de vegetação em um Neossolo Quartzarênico órtico típico, bem como estimar os níveis críticos de Pe K no solo e de $\mathrm{N}$, Pe K na matéria seca da parte aérea até 120 dias de avaliação. Os tratamentos foram dispostos em delineamento inteiramente casualizado, no esquema de fatorial fracionado $(4 \times 4 \times 4)^{1 / 2}$, perfazendo 32 tratamentos com três repetições, totalizando 96 parcelas experimentais, sendo as doses de $\mathrm{N}\left(0,75,150\right.$ e $\left.300 \mathrm{mg} \mathrm{dm}^{-3}\right)$ na forma de ureia; as de $P\left(0,45,90\right.$ e $\left.180 \mathrm{mg} \mathrm{dm}^{-3}\right)$, na forma de superfosfato triplo; e as de $K\left(0,50,100\right.$ e $\left.200 \mathrm{mg} \mathrm{dm}^{-3}\right)$, na forma de cloreto de potássio. Após 120 dias, as plantas foram colhidas e as seguintes variáveis avaliadas: altura das plantas, diâmetro do caule, matéria seca da parte aérea e de raizes, teor de macro e micronutrientes na parte aérea das plantas e atributos químicos do solo. As mudas de pinhãomanso responderam à adubação NPK na fase de inicial de crescimento; a resposta para o $N$ foi negativa, sem a necessidade de aplicação desse nutriente. A dose recomendada foi de $55 \mathrm{mg} \mathrm{dm}^{-3}$ de Pe $67 \mathrm{mg} \mathrm{dm}^{-3}$ de K. Os níveis críticos, correspondentes às doses recomendadas, foram de $13 \mathrm{mg} \mathrm{dm}^{-3}$ para Pe $74 \mathrm{mg} \mathrm{dm}^{-3}$ para Kno solo(Mehlich-1). Os teores de $\mathrm{N}$, P e K na matéria seca da parte aérea das plantas de pinhão-manso foram de 37,4, 2,1 e 35,3 $\mathrm{g} \mathrm{kg}^{-1}$, respectivamente.
\end{abstract}

Termos de indexação: adubação mineral, Jatropha curcas, oleaginosa.

\section{INTRODUCTION}

Physic nut (Jatropha curcas) belongs to the family Euphorbiaceae, the same as castor bean (Ricinus sp.), cassava (Manhiot sp.) and rubber tree (Hevea sp.), and is widely distributed in tropical and subtropical areas. Physic nut has a variety of favorable properties for oil exploration, such as: fast growth, easy propagation, perennial cycle, adaptation to areas of low and high precipitation, low seed cost, and high oil content (Sujatha et al., 2008).

Physic nut has been promoted in the last years as an alternative source of raw material for biodiesel production (Beltrão et al., 2006). Additionally, other studies showed that the trees can produce excellent yields up to 40 years (Laviola \& Dias, 2008) and a high profit by exploration of the native environment (Saturnio et al., 2005). Applications of physic nut were successful in soil conservation, green fertilizer, fuel, medicinal use and insecticide (Jongschaap et al., 2007). Physic nut is considered a rustic plant; it survives without difficulty on marginal soils with low natural fertility (Arruda et al., 2004; Saturnino et al., 2005; Dias et al., 2007; Laviola \& Dias, 2008). For high seed yields, the crop needs fertile soils and good physical conditions. Liming and fertilization are decisive factors for success and profitability with this species.

The macronutrients $\mathrm{N}, \mathrm{P}$ and $\mathrm{K}$ are the most commonly applied in the fertilization of crop plants. Nitrogen is present in the composition of the most important biomolecules such as triphosphate adenosine (ATP), chlorophyll, proteins and many enzymes (Harper, 1994). In many production systems, the availability of $\mathrm{N}$ is frequently a limiting factor, influencing plant growth more than any other nutrient (Bredemeier \& Mundstock, 2000). In the soil, organic N accounts for approximately $95 \%$ of total N (Silva \& Mendonça, 2007). Phosphorus plays an important role in the initial growth stage of crops, for being part of the so-called energy-rich compounds, such as ATP, which are absorbed by the roots as ion phosphate. Of the primary macronutrients, $\mathrm{P}$ is the one required in least quantity by plants (Malavolta, 1980). After N, P is the second most limiting nutrient for agricultural production in tropical soils, due to the low natural availability and high fixation capacity, which restrict plant growth (Holford, 1997; Araújo \& Machado, 2006, Skrebsky et al., 2008). Potassium is absorbed from the soil solution in high quantities by plants roots, but is not part of any structure or organic molecule. It is found as free or adsorbed cation, which makes it readily exchangeable from cells or tissues, with high intracellular mobility (Malavolta, 1980; Torreand \& Pereira, 2008). Plants have a capacity of absorbing more $\mathrm{K}$ than needed, which is called luxury $\mathrm{K}$ uptake (Meurer, 2006). The content ranges found in plant tissue of most crops is $5.0-60.0 \mathrm{~g} \mathrm{~kg}^{-1}$ of $\mathrm{N}$ in dry matter, 1.5-5.0 g P and 8.0-80.0 g K per kg. This variation depends on the species, the genotype and the edapho-climatic conditions of cultivation (Epstein $\&$ Bloom, 2005). 
Physic nut is a plant that responds to $\mathrm{K}$ and $\mathrm{P}$ rates, with fast initial growth (Santos et al., 2007). The production costs of crops with high nutritional requirement are very high. In the case of crops for biodiesel production, the energetic balance must be considered, which is the gross energy total supplied by the product, minus the total of the non-renewable energies spent on their production. The lack of studies on mineral nutrition of physic nut makes the commercial exploration difficult, since it is imperative to reduce input expenses to make the crop viable, economically as well as environmentally.

The purpose of this study was to evaluate physic nut growth in response to NPK rates in a greenhouse, on Quartzarenic Neossol, and to estimate the soil critical $\mathrm{P}$ and $\mathrm{K}$ levels and N, P and K levels in shoot dry matter.

\section{MATERIAL AND METHOD}

The experiment was conducted in a greenhouse of the Universidade Federal dos Vales do Jequitinhonha e Mucuri in Diamantina/MG. The soil was a typical órtic Quartzarenic Neossol (Embrapa, 2006), collected from the surface layer $(0-0.20 \mathrm{~m})$ in Diamantina/MG. Samples were crumbled, air-dried and sieved through $5.0 \mathrm{~mm}$ mesh. A subsample was taken and sieved through $2.0 \mathrm{~mm}$ mesh, forming air-dried fine earth for soil chemical (Silva, 2009) and texture analyses (Embrapa, 1997) (Table 1).

The soil was incubated in plastic pots with $\mathrm{CaCO}_{3}$ and $\mathrm{MgCO}_{3}$ p.a. at a proportion of Ca:Mg of 4:1. The quantity of lime was calculated by the incubation curve method, at a rate that would establish the soil $\mathrm{pH}$ at 6.0. The pots were incubated for 30 days, at $60 \%$ of the total pore volume (TPV) (Freire et al., 1980), monitored by daily weighing.

The experiment was arranged in a completely randomized, fractional factorial design $(4 \times 4 \times 4)^{1 / 2}$, with 32 treatments with three replications, totalizing 96 experimental plots. In the factorial design, all treatment combinations were evaluated. When this design is fractionated, some of these combinations are eliminated according to statistical tables, which vary according to the experiment (Conagin et al., 1997).
The following nutrient rates were applied: $0,75,150$ and $300 \mathrm{mg} \mathrm{dm}^{-3} \mathrm{~N}$, as urea; 0, 45, 90 and $180 \mathrm{mg} \mathrm{dm}^{-3}$ $\mathrm{P}$, as triple superphosphate, and 0, 50, 100 and $200 \mathrm{mg} \mathrm{dm}^{-3} \mathrm{~K}$, as potassium chloride. The experimental plots consisted of $5 \mathrm{dm}^{3}$ plastic pots, with no holes to avoid water draining and nutrient loss, in which $4 \mathrm{dm}^{3}$ of dry soil were filled with one seedling/ pot.

The $\mathrm{N}, \mathrm{P}$ and $\mathrm{K}$ rates, and basic micronutrient fertilization was provided according to the recommendations for pot cultivation established by Malavolta (1980), with $1.0 \mathrm{mg} \mathrm{dm}^{-3}$ of B in soil $\left(\mathrm{H}_{3} \mathrm{BO}_{3}\right), 1.5$ of $\mathrm{Cu}\left(\mathrm{CuCl}_{2}\right), 5.0$ of $\mathrm{Fe}\left(\mathrm{FeSO}_{4} .7 \mathrm{H}_{2} \mathrm{O}\right.$ EDTA), $4.0 \mathrm{mg} \mathrm{Mn}\left(\mathrm{MnCl}_{2} \cdot \mathrm{H}_{2} \mathrm{O}\right)$, and $4.0 \mathrm{mg} \mathrm{dm}^{-3}$ of $\mathrm{Zn}\left(\mathrm{ZnCl}_{2}\right)$ in soil, considering that the soil was incubated for 30 days together with the $\mathrm{P}$ rates. The $\mathrm{N}$ and K rates were split in four applications in topdressing. During the experimental period soil moisture was maintained at $60 \%$ of TPV by daily irrigations with distilled water and daily weight controls (Freire et al., 1980).

Physic nut (Jatropha curcas L.) was grown from seeds of a population provided by Company of Agricultura Research of Minas Gerais (EPAMIG), from the center in the North of the State, in Nova Porteirinha. Seeds were immersed in a solution containing the fungicide thiophanate methyl at $0.7 \%$, and the antibiotic chloramphenicol at $2 \%$. Seeds were sown in sand trays and irrigated daily with deionized water, until transplanting to the pots, which occurred when the plants had grown the first pair of permanent leaves, 35 days after seedling emergence.

The experiment was initiated in May 2007 and after a period of 120 days, the plants were harvested and the following variables evaluated: plant height, measure from the stem to the apical bud; stem diameter at the root collar, shoot dry matter (SDM) and root dry matter (RDM). Soil chemical analysis was performed after plant removal: $\mathrm{P}$ and $\mathrm{K}$ extracted by Mehlich-1. The N, P and K levels in shoot dry matter were determined according to the method described by Silva (2009).

To determine recommendable rates of $\mathrm{N}, \mathrm{P}$ and $\mathrm{K}$ for an optimized growth of plants until 120 days, a multivariate procedure was used based on the canonical variable process (Morrison, 1967). With the canonical variable of higher eigenvalue, scores were

Table 1. Soil chemical analysis and texture prior to treatment application

\begin{tabular}{|c|c|c|c|c|c|c|c|c|c|c|c|c|}
\hline pH $\mathrm{H}_{2} \mathrm{O}$ & $\mathbf{P}$ & $\mathbf{K}$ & $\mathrm{Ca}^{2+}$ & $\mathrm{Mg}^{2+}$ & $\mathrm{Al}^{3+}$ & $\mathbf{T}$ & $\mathbf{m}$ & $\mathbf{v}$ & MO & Sand & Silt & Clay \\
\hline & \multicolumn{2}{|c|}{$-\mathrm{mg} \mathrm{dm}^{-3}-$} & \multicolumn{4}{|c|}{$\longrightarrow \mathrm{cmol}_{\mathrm{c}} \mathrm{dm}^{-3}-$} & \multicolumn{2}{|c|}{ — $\%$} & $\mathrm{~g} \mathrm{dm}^{-3}$ & 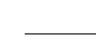 & $\mathrm{g} \mathrm{kg}^{-1}$ & - \\
\hline 5.4 & 1.4 & 10 & 0.5 & 0.4 & 0.4 & 4.2 & 30 & 22 & 12.8 & 870 & 70 & 60 \\
\hline
\end{tabular}

$\mathrm{pH}_{\text {water }}$ : Soil-water 1:2,5. P and K- Mehlich-1 extractor. $\mathrm{Ca}^{2+}, \mathrm{Mg}^{2+}$ and $\mathrm{Al}^{3+}-\mathrm{KCl} 1 \mathrm{~mol} \mathrm{~L}^{-1}$ extractor. T: Cation exchange capacity at $\mathrm{pH}$ 7.0. m: Aluminum saturation. V: Bases saturation. MO: Organic matter determined by multiplying the result of organic carbon by the Walkey-Black method by 1.724. Sand, silt and clay - Pipette method. 
obtained from the observation vector of each experimental unit of the growth variables of physic nut plants, reducing them to a single value. These scores were subjected to univariate variance analysis and regression. From the resulting equations, recommended rates were estimated to obtain $90 \%$ of the maximum value of the canonical variable.

The critical level of $\mathrm{P}$ and $\mathrm{K}$ in the soil and of N, $\mathrm{P}$ and $\mathrm{K}$ in the physic nut shoots was estimated by replacing the recommended $\mathrm{N}, \mathrm{P}$ and $\mathrm{K}$ rates in the equations that relate the $\mathrm{N}, \mathrm{P}$ and $\mathrm{K}$ rates with their contents in soil and dry matter of physic nut shoots. For the statistical procedures, the SAS for Windows program was used with PROG GLM and REG procedure.

\section{RESULTS AND DISCUSSION}

Physic nut growth was influenced by fertilization with increasing NPK rates applied to soil, with response of $\mathrm{N}$ - P interaction between and isolated response to $\mathrm{K}$ (Table 2). Based on the growth scores of physic nut of the canonical variable $(\mathrm{C} v=0.0138$ Height +0.1946 Diameter $+0.4045 \mathrm{SDM}+0.8551$ $\mathrm{RDM}$ with eigenvalue $=91 \%$ ) of the interaction between $\mathrm{N}$ and $\mathrm{P}$ a study of response surface verified growth reduction in response to increasing $\mathrm{N}$ rates and a quadratic response to increasing $\mathrm{P}$ rates (Figure 1a). Maximum growth of physic nuts was obtained without $\mathrm{N}$ application and at a $\mathrm{P}$ rate of $115 \mathrm{mg} \mathrm{dm}^{-3}$. Therefore, it was noticed that N, at the initial growth stage of physic nut, under controlled conditions, is apparently unnecessary; although the soil organic matter between 7.0 to $20.0 \mathrm{~g} \mathrm{dm}^{-3}$ (Table 1) was considered low, according to Alvarez V. et al. (1999); P on the other hand, was appropriate for an adequate plant growth.

In general, $\mathrm{N}$ is the most required nutrient by plants (Marschner, 2002). Physic nut response to N fertilization in Quartzarenic Neossol, in the plant growth stage, in this study, was not consistent with the results observed by Guimarães (2008) for the same species. In castor bean, a species of the same family as physic nut, growth was reduced when $\mathrm{N}$ was omitted (Lavres Júnior et al., 2005) but in another study, on the contrary, the growth was not reduced when no $\mathrm{N}$ was applied (Nakagawa et al., 1994). Possibly, physic nut is a species with low $\mathrm{N}$ demand at the initial stage of vegetative growth, even in soil with low organic matter content (Table 1). In this case, the replacement rate of mineral $\mathrm{N}$ in the soil solution, by mineralization of Quartzarenic Neossol organic matter would be sufficient to provide physic nut growth. Another possibility is some symbiotic association with $\mathrm{N}_{2}$ fixing microorganisms.

The initial $\mathrm{P}$ content of the soil in this study was very low (Table 1), with less than $10.0 \mathrm{mg} \mathrm{dm}^{-3} \mathrm{P}$
Table 2. Plant height, stem diameter, shoot (SDM) and root dry matter (SDR) of physic nut plants after120 days in function of $N, P$ and $K$ rates

\begin{tabular}{|c|c|c|c|c|c|}
\hline \multicolumn{2}{|c|}{ Rates } & \multirow{2}{*}{$\begin{array}{c}\text { Height } \\
\mathrm{cm}\end{array}$} & \multirow{2}{*}{$\begin{array}{c}\text { Diameter } \\
\mathrm{mm}\end{array}$} & \multirow{2}{*}{$\begin{array}{l}\text { SDM } \\
\\
\end{array}$} & \multirow{2}{*}{$\begin{array}{l}\text { SDR } \\
\mathrm{g}-\end{array}$} \\
\hline & $\mathrm{mg} \mathrm{dm} \mathrm{m}^{-3}$ & & & & \\
\hline $\mathrm{N}$ & $\mathrm{P}$ & & & & \\
\hline \multirow[t]{4}{*}{0} & 0 & 13.2 & 8.3 & 1.6 & 0.31 \\
\hline & 45 & 13.8 & 9.0 & 1.7 & 0.37 \\
\hline & 90 & 16.1 & 11.8 & 2.5 & 0.68 \\
\hline & 180 & 14.3 & 10.3 & 1.8 & 0.47 \\
\hline \multirow[t]{4}{*}{75} & 0 & 13.5 & 8.0 & 1.2 & 0.28 \\
\hline & 45 & 13.6 & 8.3 & 1.4 & 0.40 \\
\hline & 90 & 15.9 & 9.5 & 2.3 & 0.46 \\
\hline & 180 & 13.7 & 9.5 & 1.7 & 0.44 \\
\hline \multirow[t]{4}{*}{150} & 0 & 11.3 & 5.3 & 0.4 & 0.12 \\
\hline & 45 & 11.8 & 5.5 & 0.8 & 0.27 \\
\hline & 90 & 15.6 & 10.5 & 3.0 & 0.83 \\
\hline & 180 & 12.3 & 7.3 & 1.3 & 0.28 \\
\hline \multirow[t]{4}{*}{300} & 0 & 10.4 & 6.0 & 0.6 & 0.14 \\
\hline & 45 & 10.6 & 7.0 & 0.7 & 0.25 \\
\hline & 90 & 13.4 & 9.0 & 1.4 & 0.37 \\
\hline & 180 & 12.8 & 8.0 & 1.3 & 0.35 \\
\hline \multicolumn{2}{|c|}{ K Rates (mg dm $\left.{ }^{-3}\right)$} & Height & Diameter & SDM & SDR \\
\hline & 0 & 12.0 & 6.6 & 0.9 & 0.25 \\
\hline & 50 & 13.9 & 8.4 & 1.3 & 0.40 \\
\hline & 100 & 14.1 & 9.3 & 1.9 & 0.47 \\
\hline & 200 & 13.1 & 8.9 & 1.8 & 0.39 \\
\hline Aver & & 13.3 & 8.3 & 1.5 & 0.37 \\
\hline $\mathrm{CV}\left({ }^{\circ}\right.$ & & 14.1 & 16.1 & 11.0 & 14.7 \\
\hline
\end{tabular}

(Alvarez V. et al., 1999), which is the reason why phosphate fertilization provided maximum physic nut growth (Figure 1a). This demonstrated the potential limitation of Quartzarenic Neossol to maintain the initial growth of physic nut without correction of the natural fertility; the deficiency of this nutrient is the most relevant nutritional factor for restricted plant growth on tropical soils (Skrebsky et al., 2008). Additionally, the growth rate of juvenile physic nut is particularly high (Santos et al., 2007), making it very responsive to phosphate fertilization (Laviola \& Dias, 2008).

Physic nut growth, evaluated by canonical variable scores, increased according to a quadratic model with the increasing K rates; maximum growth was obtained by a rate of $138 \mathrm{mg} \mathrm{dm}^{-3} \mathrm{~K}$ (Figure $1 \mathrm{~b}$ ). There are great differences among plant species in terms of the appropriate $\mathrm{K}$ level for initial growth (Nicoloso et al., 2001). Eucalyptus seedlings in Latossol did not respond to the application of potassium chloride, resulting in a $\mathrm{K}$ content of only $6.0 \mathrm{mg} \mathrm{dm}^{-3}$ by 


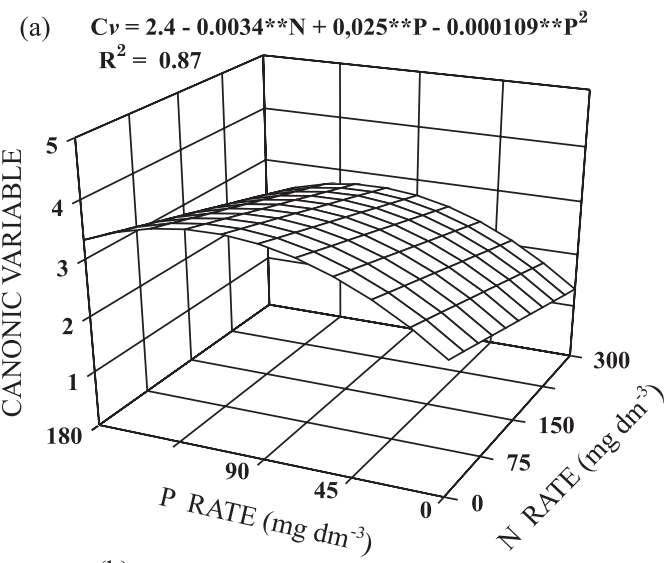

(b)

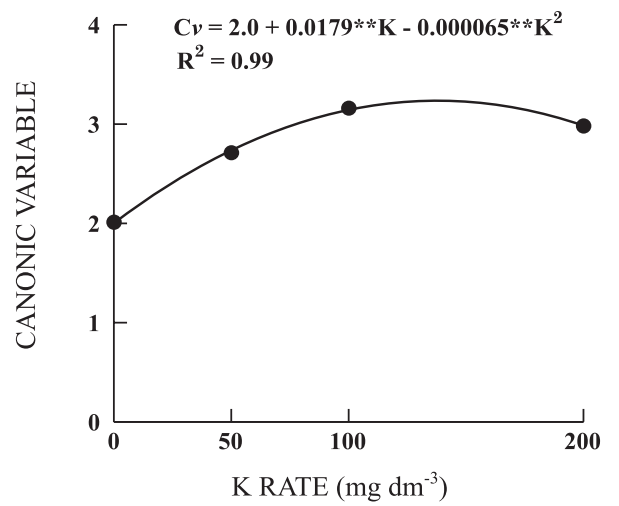

Figure 1. Canonical variable score of multivariate analysis as a function of $\mathrm{N}$ and $\mathrm{P}$ rates in the interaction (a) and of $K(b)$ of physic nut $(* *$ significant at $1 \%$ by the $t$ test).

extractor Mehlich-1 (Novais et al., 1979). On the other hand, the review of several studies showed that the adequate soil content would be $40-60 \mathrm{mg} \mathrm{dm}^{-3} \mathrm{~K}$, for most annual crops (Novais et al., 1990). For physic nut, in cases of a low soil $\mathrm{K}$ content (less than $15.0 \mathrm{mg} \mathrm{dm}^{-3}$ ) (Figure 1) (Alvarez V. et al., 1999), it was observed that potassium fertilization was beneficial for several growth variables (Table 2) and for the response to $\mathrm{K}$ rates (Figure $1 \mathrm{~b}$ ). For cassava (Manihot esculenta L.), member of the same family as physic nut, grown on a Dark Red Argissol at a soil $\mathrm{K}$ content between 43 and $82 \mathrm{mg} \mathrm{dm}^{-3}$, there was no response to K fertilization (Fidalski, 1999). The species umbuzeiro (Spondias tuberose Arr. Cam.), found in the semi-arid regions of Brazil, has a similar physiological behavior to physic nut, with high foliar $\mathrm{K}$ contents of potassium-fertilized plants (Neves et al., 2007).

The recommended $\mathrm{P}$ and $\mathrm{K}$ rate to obtain $90 \%$ of the maximum growth of physic nut was estimated by the adjusted equation of the canonical variable $(\mathrm{Cv})$ and $\mathrm{P}$ rates to soil without $\mathrm{N}$ fertilization (Figure 1a), determining a $\mathrm{P}$ rate of $55 \mathrm{mg} \mathrm{dm}^{-3}$, and $\mathrm{K}$, estimated by the quadratic equation (Figure $1 \mathrm{~b}$ ), at $67 \mathrm{mg} \mathrm{dm}^{-3}$ $\mathrm{K}$. These $\mathrm{K}$ and $\mathrm{P}$ fertilization rates for physic nut in
Quartzarenic Neossol apply only to the initial growth stage under greenhouse conditions.

By the replacement of $\mathrm{P}$ and $\mathrm{K}$ rates corresponding to $90 \%$ of the maximum growth of physic nut, in linear equations that related $\mathrm{P}$ and $\mathrm{K}$ contents as dependent variables of $\mathrm{P}$ and $\mathrm{K}$ rates (Figure 2 ), the critical level of $\mathrm{P}$ and $\mathrm{K}$ corresponding to this growth level was estimated. The critical levels (CL) in the soil were calculated as $13.0 \mathrm{mg} \mathrm{dm}^{-3}$ for $\mathrm{P}$ (Figure 2a) and $74.0 \mathrm{mg} \mathrm{dm}^{-3}$ for $\mathrm{K}$ (Figure $2 \mathrm{~b}$ ); these values are considered low and medium, respectively, according to Alvarez V. et al. (1999).

For the leaf levels of N, P and K, the same procedure as for soil-available $\mathrm{P}$ and $\mathrm{K}$ was carried out, in which the critical levels of $\mathrm{N}, \mathrm{P}$ and $\mathrm{K}$ was estimated in the shoot dry matter of physic nut. The $\mathrm{N}, \mathrm{P}$ and $\mathrm{K}$ levels in shoot dry matter responded linearly to N, P and $\mathrm{K}$ fertilization (Figure 3). The critical levels were $37.4 \mathrm{~g} \mathrm{~kg}^{-1} \mathrm{~N}$ (Figure 3a), $2.1 \mathrm{~g} \mathrm{~kg}^{-1}$ $\mathrm{P}$ (Figure $3 \mathrm{~b}$ ) and $35.3 \mathrm{~g} \mathrm{~kg}^{-1} \mathrm{~K}$ (Figure $3 \mathrm{c}$ ). Since the growth of physic nut plants decreased linearly in relation to the $\mathrm{N}$ rates, i.e, the increase of $\mathrm{N}$ rates
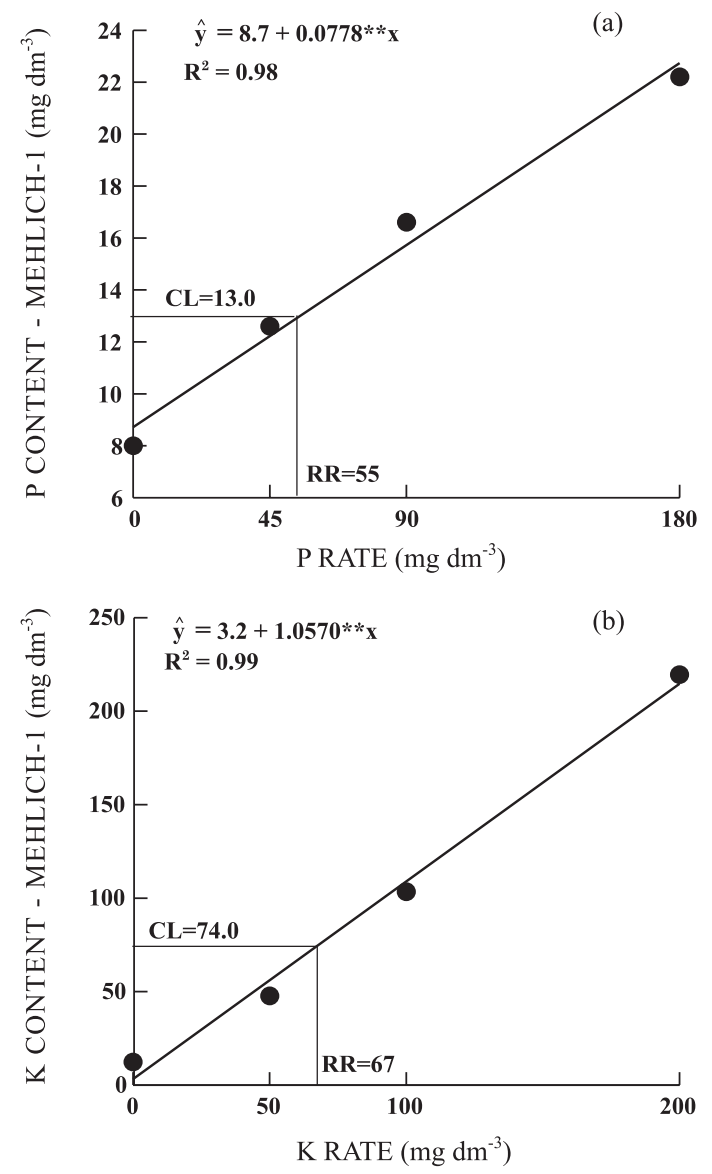

Figure 2. Phosphorus and $K$ content available (Mehlich-1) as a function of $P$ and $K$ rates applied to soil and critical level (CL) for the recommended rate ( $R R$ ) in physic nut cultivation (** significant at $1 \%$ by the t test). 
resulted in growth reduction (Figure 1a), the $\mathrm{N}$ critical level was estimated at nutrient rate zero, since it provided the maximum vegetative growth. The critical concentration in physic nut shoots is, in general, within the levels of tissues of cultivated plants: $5.0-60.0 \mathrm{~N}, 1.5-5.0 \mathrm{~g} \mathrm{P}$ and $8.0-80.0 \mathrm{~g} \mathrm{~kg}^{-1}$ $\mathrm{K}$ in dry matter; the variation is related to the genotype, soil and other factors (Epstein \& Bloom, 2005). The foliar contents of $\mathrm{N}$ and $\mathrm{P}$ are close and those of $\mathrm{K}$ higher than determined in physic nut leaves on branches with inflorescence of $31.4,2.8$ and $13.7 \mathrm{~g} \mathrm{~kg}^{-1}$, respectively (Laviola \& Dias, 2008).

Plants grown on soils with lower clay contents have higher $\mathrm{P}$ shoot contents (Silva et al., 2001), probably because the $\mathrm{P}$ buffer capacity in sandy is
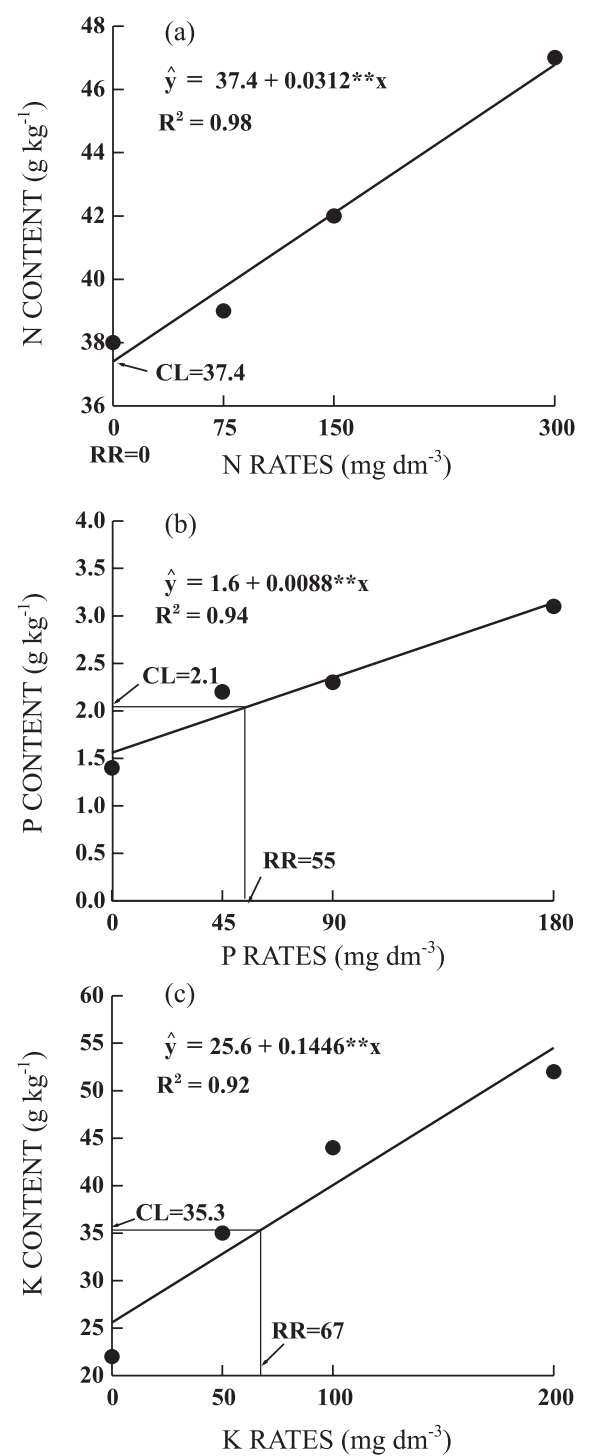

Figure 3. N, P and K contents in physic nut shoots as a function of $\mathrm{N}, \mathrm{P}$ and $\mathrm{K}$ rates applied to soil and critical level (CL) for recommended rate (RR). (** significant at $1 \%$ by the t test). lower than in clay soils (Novais \& Smyth, 1999). Therefore, the same P quantity absorbed by plants would reduce the $\mathrm{P}$ concentration in solution proportionally more in sandy than in clay soil. Therefore, this is related to the low and high critical $P$ level available in soil and in leaf dry matter of physic nut, respectively.

\section{CONCLUSIONS}

1. Physic nut responded to NPK fertilization in the initial seedling growth stage, sparing $\mathrm{N}$ application and $\mathrm{P}$ and $\mathrm{K}$ quantities of $55 \mathrm{mg} \mathrm{dm}^{-3} \mathrm{P}$ and $67 \mathrm{mg} \mathrm{dm}^{-3} \mathrm{~K}$, respectively, are recommended for Quartzarenic Neossol for 120 days of growth.

2 . The soil critical levels obtained with recommended rates were 13.0 for $\mathrm{P}$ and $77.0 \mathrm{mg} \mathrm{dm}^{-3}$ for $\mathrm{K}$ (Mehlich-1).

3. The critical levels of $\mathrm{N}, \mathrm{P}$ and $\mathrm{K}$ in shoot dry matter of physic nut were 37.4; 2.1 and $35.3 \mathrm{~g} \mathrm{~kg}^{-1}$, respectively.

\section{ACKNOWLEDGEMENTS}

The authors are indebted to the National Council of Scientific and Technological Development (CNPq) and Fundação de Amparo à Pesquisa do Estado de Minas Gerais (FAPEMIG), for financial support and to the Brazilian Federal Agency for Support and Evaluation of Graduate Education (CAPES), for a master fellowship. They also thank the Federal University of Jequitinhonha and Mucuri Valleys (UFVJM), for the infrastructure and the Empresa de Pesquisa Agropecuária de Minas Gerais (EPAMIG) of the Centro Tecnológico Norte de Minas in Nova Porteirinha/MG, for providing physic nut seedlings.

\section{LITERATURE CITED}

ALVAREZ V., V.H.; NOVAIS, R.F.; BARROS, N.F.; CANTARUTTI, R.B. \& LOPES, A.S. Interpretação dos resultados das análises de solos. In: RIBEIRO, A.C.; GUIMARÃES, P.T.G. \& ALVAREZ V., V.H., eds. Recomendações para o uso de corretivos e fertilizantes em Minas Gerais. Viçosa, MG, CFSEMG, 1999. p.25-32.

ARAÚJO, A.P. \& MACHADO, C.T.T. Fósforo. In: FERNANDES, M.S. Nutrição mineral de plantas. Viçosa, MG, Sociedade Brasileira de Ciência do Solo, 2006. p.253280 .

ARRUDA, F.P.; BELTRÃO, N.E.M.; ANDRADE, A.P.; PEREIRA, W.E. \& SEVERINO, L.S. Cultivo de pinhão manso (Jatropha curcas L.) como alternativa para o semiárido nordestino. R. Bras. Oleag. Fibrosas, 8:789799,2004 
BELTRÃO, N.E.M.; SEVERINO VELOSO, J.F.; JUNQUEIRA, N.; FIDELIS, M.; GONÇALVES, N.P.; SATURNINO, H.M.; ROSCOE, R.; GAZZONI, D.; DUARTE, J.O.; DRUMOND, M.A. \& ANJOS, J.B. Alerta sobre o plantio de pinhão manso no Brasil. Campina Grande, Embrapa Algodão, 2006. 15p. (Documentos, 155)

BREDEMEIER, C. \& MUNDSTOCK, C.M. Regulação da absorção e assimilação do nitrogênio nas plantas. Ci. Rural, 30:365-372, 2000.

CONAGIN, A.; NAGAI, V. \& IGUE, T. Delineamento (1/2) $4 \geq$ em blocos de oito unidades. Campinas, Instituto Agronômico de Campinas, 1997. 9p. (Boletim Científico, 36)

DIAS, L.A.S.; LEME, L.P.; LAVIOLA, B.G.; PALLINI FILHO, A.; PEREIRA, O.L.; CARVALHO, M.; MANFIO, C.E.; SANTOS, A.S.; SOUSA, L.C.A.; OLIVEIRA, T.S. \& DIAS, D.C.F.S. Cultivo de pinhão-manso (Jatropha curcas L.) para produção de óleo combustível. Viçosa, MG, 2007. v.1. $40 \mathrm{p}$.

EMPRESA BRASILEIRA DE PESQUISA AGROPECUÁRIA . EMBRAPA. Centro Nacional de Pesquisa de Solos. Sistema brasileiro de classificação de solos. Brasília, Produção de Informação, 2006. 306p.

EMPRESA BRASILEIRA DE PESQUISA AGROPECUÁRIA EMBRAPA. Centro Nacional de Pesquisa de Solos. Manual de métodos de análise do solo. Brasília, Produção de Informação, 1997. 212p.

EPSTEIN, E. \& BLOOM, A.J. Mineral nutrition of plants: Principles and perspectives. 2.ed. Sunderland, Sinauer Associates, 2005. 400p.

FIDALSKI, J. Respostas da mandioca à adubação NPK e calagem em solos arenosos do noroeste do Paraná. Pesq. Agropec. Bras., 34:1353-1359, 1999.

FREIRE, J.C.; RIBEIRO, M.A.V.; BAHIA, G.V.; LOPES, A.S. \& AQUINO, L.H. Resposta do milho cultivado em casa de vegetação a níveis de água em solo da região de Lavras, MG. R. Bras. Ci.Solo, 4:5-8, 1980

GUIMARÃES, A.S. Crescimento inicial do pinhão manso (Jatropha curcas L.) em função de fontes e quantidades de fertilizantes. Areia, Universidade Federal da Paraíba, 2008. 92p. (Tese de Doutorado)

HARPER, J.E. Nitrogen metabolism. In: BOOTE, K.J.; BENNETT, J.M.; SINCLAIR, T.R. \& PAULSEN, G.M., eds. Physiology and determination of crop yield. Madison, ASA/CSSA/SSSA, 1994. p.285-302.

HOLFORD, I.C.R. Soil phosphorus: Its measurement, and its uptake by plants. Austr. J. Soil Res., 35:227-239, 1997.

JONGSCHAAP, R.E.E.; CORRÉ, W.J.; BINDRABAN, P.S. \& BRANDENBURG, W.A. Claims and facts on Jatropha curcas L.: Global Jatropha curcas evaluation, breeding and propagation programme. Wageningen, Plant Res. Internat., 2007. 66p.

LAVIOLA, B.G. \& DIAS, L.A.S. Teor e acúmulo de nutrientes em folhas e frutos de pinhão-manso. R. Bras. Ci. Solo, 32:1969-1975, 2008.
LAVRES JÚNIOR, J.; BOARETTO, R.M.; SILVA, M.L.S.; CORREIA, D.; CABRAL, C.P. \& MALAVOLTA, E. Deficiências de macronutrientes no estado nutricional da mamoneira cultivar Íris. Pesq. Agropec. Bras., 40:145151,2005 .

MALAVOLTA, E. Elementos de nutrição mineral de plantas. Piracicaba, Ceres, 1980. 251p.

MARSCHNER, H. Mineral nutrition of higher plants. London, Academic, 2002. 889p.

MEURER, E.J. Potássio. In: FERNANDES, M.S. Nutrição mineral de plantas. Viçosa, MG, Universidade Federal de Viçosa, 2006. p.281-298.

MORRISON, D.F. Multivariate statical methods. New York, Mc Graw-Hill Book, 1967. 415p.

NAKAGAWA, J.; NAKAGAWA, J. \& FERNANDES, D.M. Importância da adubação na qualidade do amendoim e da mamona. In: SÁ, M.E. \& BUZZETI, S., eds. Importância da adubação na qualidade dos produtos agrícolas. São Paulo, Ícone, 1994. p.289-318.

NEVES, O.S.C.; CARVALHO, J.G.; FERREIRA, E.V.O. \& PEREIRA, N.V. Crescimento, nutrição mineral e nível crítico foliar de $\mathrm{K}$ em plantas de umbuzeiro, em função da adubação potássica. Ci. Agrotec., 31:636-642, 2007.

NICOLOSO, F.T.; FOGAÇA, M.A.F.; ZANCHETTI, F. \& MISSIO, E. Nutrição mineral de mudas de grápia (Apuleia leiocarpa) em Argissolo Vermelho distrófico arênico: (1) Efeito da adubação NPK no crescimento. Ci. Rural, 31:991-998, 2001.

NOVAIS, R.F. \& SMYTH, T.J. Fósforo em solo e planta em condições tropicais. Viçosa, MG, Universidade Federal de Viçosa, 1999. 399p.

NOVAIS, R.F.; BARROS, N.F. \& NEVES J.C.L. Nutrição mineral do eucalipto. In: BARROS, N.F. \& NOVAIS, R.F. Relação solo-eucalipto. Viçosa, MG, Universidade Federal de Viçosa, 1990. p.25-98.

NOVAIS, R.F., GOMES, J.M. \& ROCHA, D. Calagem e adubação mineral na produção de mudas de eucalipto (Eucalyptus grandis W. HiII ex Maiden): 1-Efeito da calagem e dos nutrientes N, P e K. R. Árvore, 3:12l-134, 1979 .

SANTOS, S.; FERREIRA JUNIOR, E.J.; PIRES, B. \& NETTO, A.P.C. Efeito de diferentes adubações no desenvolvimento inicial de plantas de pinhão-manso (Jatropha curcas L.). In: CONGRESSO BRASILEIRO DE PLANTAS OLEAGINOSAS, ÓLEOS, GORDURAS E BIODIESEL, 4., Varginha, 2007. Anais... Lavras, Universidade Federal de Lavras, 2007. p.547-554.

SATURNINO, H.M.; PACHECO, D.D.; KAKIDA, J.; TOMINAGA, N. \& GONÇALVES, N.P. Cultura do pinhãomanso (Jatropha curcas L.). Inf. Agropec., 26:44-78, 2005.

SILVA, E.B.; RESENDE, J.C.F. \& CINTRA, W.B.R. Resposta do feijoeiro a doses de fósforo em solo arenoso. Ci. Rural, 31:973-977, 2001.

SILVA, F.C. Manual de análises químicas de solos, plantas e fertilizantes. 2.ed. Brasília, Embrapa Informações Tecnológicas, 2009. 627p. 
SILVA, I.R. \& MENDONÇA, E.S. Matéria orgânica do solo. In: NOVAIS, R.F.; ALVAREZ V., V.H.; BARROS, N.F.; FONTES, R.L.F.; CANTARUTTI, R.B. \& NEVES, J.C.L., eds. Fertilidade do solo. Viçosa, MG, Sociedade Brasileira Ciência do Solo, 2007. p.275-354.

SKREBSKY, E.C.; NICOLOSO, F.T.; MALDANER, J.; RAUBER, R.; CASTRO, G.Y.; JUCOSKI, G.O. \& SANTOS, D.R. Caracterização das exigências nutricionais de plantas de Paffia glomerata em Argissolo Vermelho distrófico arênico pela técnica do nutriente faltante. Ci. Rural, 38:989-996, 2008.
SUJATHA, M.; REDDY, T.P. \& MAHASI, M.J. Role of biotechnological interventions in the improvement of castor (Ricinus communis L.) and Jatropha curcas L. Biotechnol. Adv., 26:424-435, 2008.

TORRES, J.L.R. \& PEREIRA, M.G. Dinâmica do potássio nos resíduos vegetais de plantas de cobertura no Cerrado. R. Bras. Ci. Solo, 32:1609-1618, 2008. 